\title{
Morphometry and performance of Black Bengal goats at the rural community level in Bangladesh
}

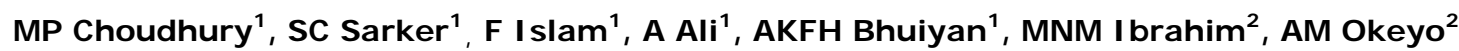 \\ ${ }^{1}$ Department of Animal Breeding and Genetics, Bangladesh Agricultural University, Mymensingh 2202, \\ Bangladesh; ${ }^{2}$ International Livestock Research Institute (ILRI), Nairobi, Kenya
}

\begin{abstract}
Data on morphometrics and performance of 106 Black Bengal goats were collected through an in-depth monitoring survey conducted in 73 families of Gangatia, Borachala and Pachpai villages of Bhaluka Upazila, Mymensingh, Bangladesh using a structured questionnaire. Analyses of variance were performed using the General Linear Model (GLM) procedure under Statistical Package for the Social Sciences (SPSS) version 14.0. Differences between mean values were separated using Duncun's Multiple Range Test (DMRT). Body weight of goats significantly $(p<0.001)$ differed with age classes and body condition scores. Average body weight of Black Bengal goat was $14.47 \pm 0.48 \mathrm{~kg}$. Body length at was $46.01 \pm 0.66 \mathrm{~cm}$. Chest girth significantly $(p<0.001)$ differed with age classes and body condition scores. Average chest girth of Black Bengal goat was $56.10 \pm 0.60 \mathrm{~cm}$. Wither height significantly $(p<0.001)$ differed with age classes and body size. Average wither height of Black Bengal goat was $46.41 \pm 0.36 \mathrm{~cm}$. Scrotal length and scrotal circumference did not significantly $(p>0.05)$ differ with age classes, villages and body condition. The number of services needed for each conception of Solid Black, Toggenburg pattern and Brown Bezoar goats were 1.32 $\pm 0.31,1.08 \pm 0.22,1.25 \pm 0.31,1.01 \pm 0.26$ and $1.23 \pm 0.27$, respectively. The lowest kidding interval was observed in Borachala village (169.80 \pm 38.11 days) and in Solid Black goats (176.71 \pm 36.17 days). The highest litter size was found in does $(1.68 \pm 0.39)$ of Gangatia village $(1.67 \pm 0.51)$ and in Solid Black goats (1.67 \pm 0.54$)$. The lowest abortion rate was found in Solid Black goats $(6.14 \%)$. The lowest kid mortality was observed in Solid Black goats $(10.00 \%)$. Variation observed in morphometric and production traits of indigenous Black Bengal goats indicated an opportunity for their improvement through an in-situ pure breeding program.
\end{abstract}

Key words: Black Bengal goat, coat color, morphometry, reproductive performance.

Bangladesh Animal Husbandry Association. All rights reserved. $\quad$ Bang. J. Anim. Sci. 2012. 41 (2): 83-89

\section{Introduction}

Goats play an important role in livelihoods of smallholder farmers in Bangladesh as they serve as assets that can be easily liquidated to provide cash in times of need Akhter et al. (2006). Bangladesh has the second highest population of goat among the Asiatic countries which accounts for about 60.60 million heads representing $57 \%$ of total ruminant livestock and more than $90 \%$ of the goats of the country are of the Black Bengal breed Husain (1993); Amin et al. (2001). Black Bengal goats are dwarf goats and are known to be famous for its adaptability, higher disease resistant, fertility, fecundity, early sexual maturity, larger litter size, delicacy of meat and superior skin quality Islam (2001); Devendra and Burns (1983); Hussain et al. (1998). Though majorities of the Black Bengal bear black coat color, black and white, brown, brown and white and white coat color colors are also common in the Black Bengal population. They are more or less evenly distributed throughout the country with a relatively higher concentration in the northwestern area of Bangladesh. It is also found throughout the eastern and north eastern India. Goats are deeply embedded in almost all over Bangladeshi culture and are considered as true friends to the rural poor. The old saying that "the goat is the poor man's cow" still holds true in the majority of developing countries. Goats play a unique role in supporting some of the poorest people in Bangladesh and can play a powerful role in lifting them out of poverty towards prosperity Amin (2000). Goat rearing is considered as one of the main means of survival for many women in remote villages. More importantly, above $98 \%$ of Black Bengal goats are being managed in the traditional village system of the country (Husain et al.1998) where mature and quality breeding bucks are not available. Government or private breeding service is not available in the rural villages too. Goat raising community therefore can organize among them self to produce breeding bucks for their use. There are no previous research attempts in this regard in Bangladesh 
Husain (2004). So, it is worth testing the research model for improving Black Bengal goats in Bangladesh through community managed breeding flock. Therefore, the present study was undertaken to investigate the morphometry and performance of Black Bengal goats at community level.

\section{Materials and Methods}

The experiment was conducted at rural community level goat flocks of Gangatia, Borachala and Pachpai villages under Bhaluka Upazila of Mymensingh district of Bangladesh. Bhaluka is located at $24.3750^{\circ} \mathrm{N}$; $90.3778^{\circ} \mathrm{E} 24.3750 ; 90.3778$. The ecology of three villages of Bhaluka is more or less same. The temperature ranges from $12^{\circ} \mathrm{C}$ to $33^{\circ} \mathrm{C}$, and the annual rainfall averages $2147 \mathrm{~mm}$. Data from a total of 106 goats measured in 73 households under the community based goat flocks were included in this study. The farmers were selected randomly using the UNEP-GEF-ILRI FAnGR Asia Project developed baseline survey questionnaire at the said three different villages.

Age classes of goats were: Kids $=$ birth to weaning, Yearling $=$ weaning to 11 months, Replacement females $=12$ to 18 months, Bucks=adult males $>12$ months and Does=adult females > 18 months. According to coat color variation, goats were categorized into: i) Solid Black locally called deshi chaagol, ii) Toggenburg pattern locally called boiragi chaagol, iii) Brown Bezoar locally called Shiyailla chaagol, iv) Dutch belt, v) Silver Bezoar and vi) different other combinations. Different coat colors of goats are shown in the Figure 1 . Body weight of the individual goat was taken from all age classes. Animals were weighed using weighing scale. Body weight was recorded in $\mathrm{kg}$. Body condition of goats was recorded according to the farmer's and enumerator's observation. The following body measurements were considered for morphometric study of Black Bengal goats. Body length, chestgirth, wither height, scrotal length and scrotal circumference. Different body measurements, scrotal length and scrotal circumference were taken by a measuring tape in centimeter $(\mathrm{cm})$.

The recorded reproductive traits at community level flocks were number of services per conception, litter size, kidding interval, abortion rate, mortality rate of kids and type of breeding practices.

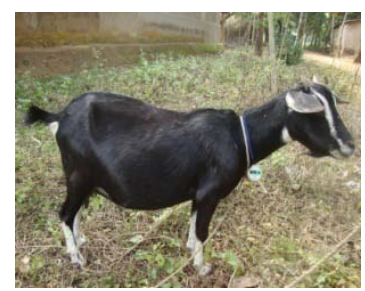

Solid Black

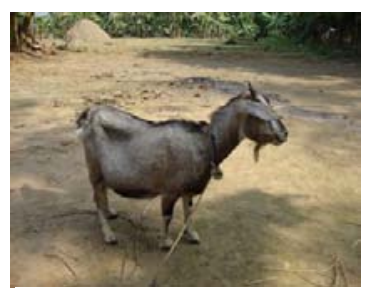

Brown with Toggenburg

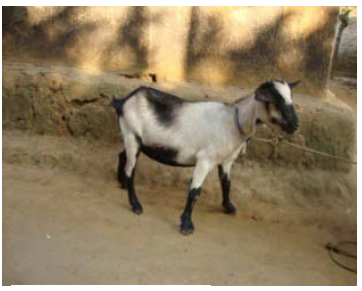

Silver Bezoa

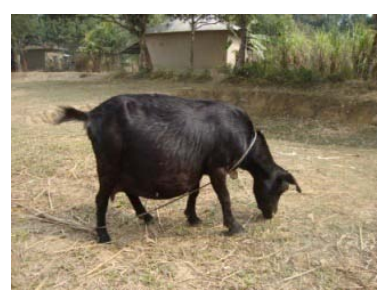

Black with Toggenburg pattern

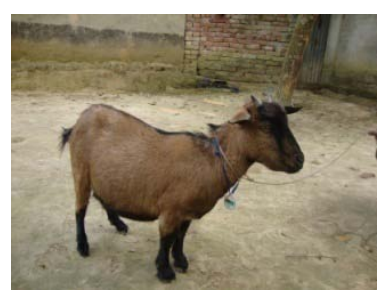

Brown Bezoar

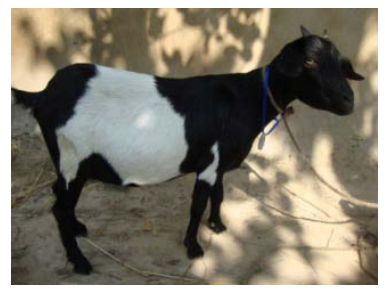

Black with Dutch belt spotting

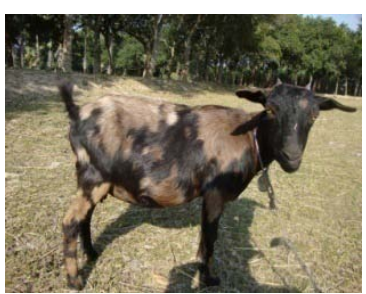

Other combination

Figure 1. Different coat colors of Black Bengal goat (Source: Nozawa et al. 1984; Faruque and Khandoker 2007)

All the data obtained from the three villages covering all the community goats were organized, structured and analysis of variance were performed using the General Linear Model (GLM) procedure under Statistical Package for the Social Sciences (SPSS) version 14.0. In addition, for significant variables, means were separated using Duncan's Multiple Range Test (DMRT).

The following general linear statistical models were used.

\section{Model a:}

$Y_{i j k l m n}=\mu+A_{i}+V_{j}+B_{k}+H_{l}+C m+e_{i j k l m n}$

where,

$Y_{i j k l}$ is the dependent variable (body weight, body length, chest girth and wither height) of the 


\section{Characteristics of Black Bengal goat}

experiment; $\mu$ is the overall mean; $A i_{\text {is the }}$ effect of the $i^{\text {th }}$ age class; $V_{j}$ is the effect of the $j^{\text {th }}$ village; $B_{k}$ is the effect of the $k^{\text {th }}$ body condition; $H_{1}$ is the effect of the $I^{\text {th }}$ horn pattern; $C_{m}$ is the effect of the $\mathrm{m}^{\text {th }}$ coat color and $e_{\mathrm{ijklmn}}$ is the error term. There were very few observations on mature males and hence the analysis excluded sex as a main effect in the above model.

\section{Model b:}

$Y_{i j k l m n o} \mu+A_{i}+V_{j}+C_{k}+T_{l}+S_{m}+K_{n}+L_{o}+$ $\mathrm{e}_{\mathrm{ijk} k m n o}$

where,

$\mathrm{Y}_{\mathrm{ijkl}}$ is the dependent variable (service per conception, kidding interval and litter size) of the experiment; $\mu$ is the overall mean; $A_{i}$ is the effect of the $i^{\text {th }}$ age class, $V_{j}$ is the effect of the $j^{\text {th }}$ village,$C_{k}$ is the effect of the $k^{\text {th }}$ coat color, $T_{1}$ is the effect of the $I^{\text {th }}$ type of breeding practices, $S_{m}$ is the effect of the $m^{\text {th }}$ service per conception $K_{n}$ is the effect of the $n^{\text {th }}$ kidding interval, Lo is the effect of the $o^{\text {th }}$ litter size and $e_{i j k l m n o}$ is the error term.

\section{Results}

Out of 165 Households, 73 households were found as family goat raiser. About $42.5 \%$ had 1 goat, $31.5 \%$ had 2 goats, $13.7 \%$ had 3 goats, $6.8 \%$ had 4 goats, $4.1 \%$ had 5 goats, and $1.4 \%$ had 8 goats. At three villages, does and bucks of Black Bengal goats appeared at the ratio of 92.45: 7.55. Doe $(100 \%)$ was highest in Gangatia than that of other villages. Buck (11\%) was highest in Pachpai than that of other villages (Figure 4.1: a-d). Solid Black $(42 \%)$ was highest among others coat color of goats in all the three villages. Percent of Solid Black Bengal (65) was highest in Pachpai than that of other two villages. Toggenburg pattern (55\%) was highest in Gangatia than that of other villages. Brown Bezoar was very similar (18-19\%) in Gangatia and Borachala but lower in Pachpai. Other combination (14\%) was highest in Borachala and lower in Pachpai.

Table 1. Distribution of percentage of goats according to sex in each village

\begin{tabular}{lllll}
\hline Sex & Gangatia & Borachala & Pachpai & Total \\
\hline Male & 0 & 9 & 11 & 8 \\
Female & 100 & 91 & 89 & 92 \\
\hline
\end{tabular}

Other

Combination (8\%)

Dutch belt $1 \%$

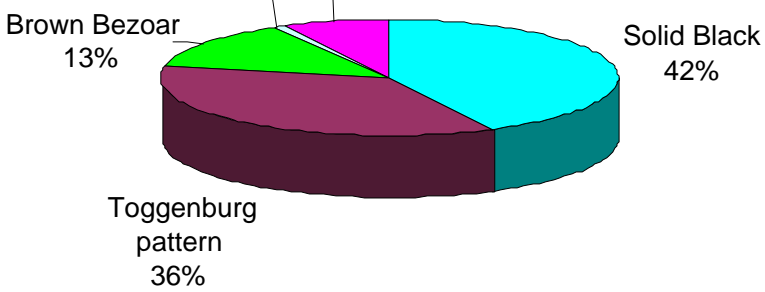

a) Coat color distribution of goat in all villages Other

Combination (7\%)

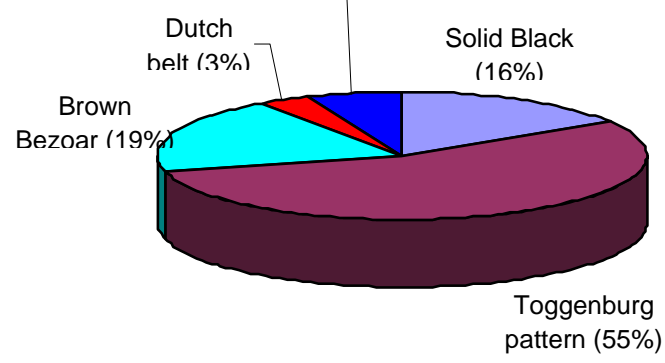

b) Coat color distribution of goat in Gangatia

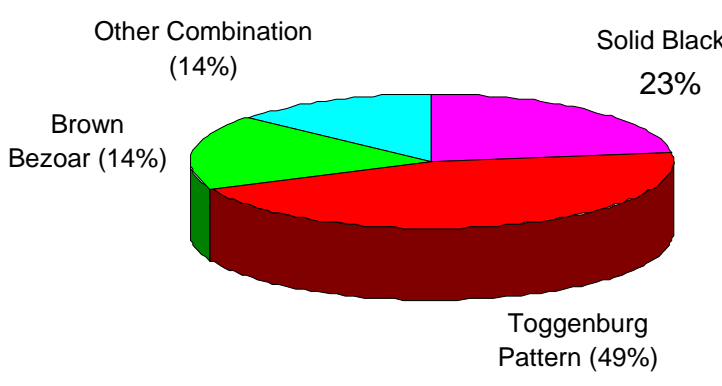

c) Coat color distribution of goat in Borachala

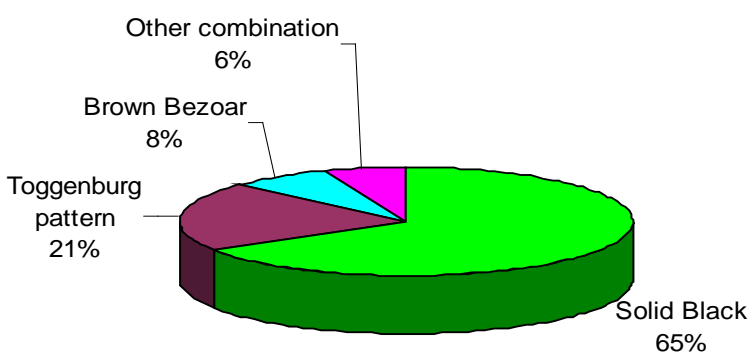

d) Coat color distribution of goat in Pachpai

Figure 4. Coat color distribution pattern in different villages $(a-d)$ 
Table 1 shows the effect of different factors on body weight of goats. The effects of age class and body condition were highly significant $(p<0.001)$, while no significant effects $(p>0.05)$ were found for the village, horn pattern and coat color. Minimum and maximum body weight of Black Bengal goats in this study were 6.50 and 28.00 $\mathrm{kg}$. The average body weight of Black Bengal goat was $14.47 \pm 0.48 \mathrm{~kg}$. Table 1 also shows the effect of different factors on body length on goats. The effect of age class was significant $(p<0.001)$ on body length of goats while no significant effect $(p>0.05)$ was found for village, body condition, horn pattern and coat color. Minimum and maximum body length of Black Bengal goat in this study was found to be 35.00 and $87.00 \mathrm{~cm}$, respectively. The average body length of Black Bengal goat was $46.01 \pm 0.66 \mathrm{~kg}$.

It also appeared from Table 1 that effect of age class, village and body condition was significant $(p<0.001)$ on chest girth while no significant effect $(p>0.05)$ was found for horn pattern and coat color. Minimum and maximum body length of
Black Bengal goat in this study was found to be 44.00 and $72.00 \mathrm{~cm}$ respectively. The average chest girth of Black Bengal goat was $56.10 \pm 0.60$ $\mathrm{kg}$. And table 1 shows the effect of different factors on wither height of goats. Analysis of variance shows that effect of age class was significant $(p<0.001)$ on wither height while no significant $(p>0.05)$ results were found for village, body condition, horn pattern and coat color. Minimum and maximum wither height of Black Bengal goat in this study was found to be 39.00 and $56.00 \mathrm{~cm}$, respectively. The average body length of Black Bengal goat was $46.41 \pm 0.36 \mathrm{~kg}$.

\section{Reproductive traits}

The range of kidding interval, litter size and service per conception of Black Bengal goats were 150-365 days, 1-4 kids, 1-2 kids, respectively. The average kidding interval, litter size and service per conception of Black Bengal goats were 188.55 \pm 8.62 days, $1.58 \pm 0.09$ and $1.10 \pm 0.05$, respectively.

Table1: Effect of different factors on body weight, body length, chest girth and wither height

\begin{tabular}{|c|c|c|c|c|c|c|}
\hline \multirow{2}{*}{ Factor } & \multirow{2}{*}{ Category } & \multirow{2}{*}{$\mathrm{n}$} & \multicolumn{3}{|c|}{ Mean \pm SE } & \multirow[b]{2}{*}{$\mathrm{WH}$} \\
\hline & & & BWT & $\mathrm{BL}$ & CG & \\
\hline \multicolumn{3}{|c|}{ Level of Significance } & $* * *$ & $* * *$ & $* * *$ & $* * *$ \\
\hline \multirow{3}{*}{$\begin{array}{l}\text { Age } \\
\text { (months) }\end{array}$} & \multirow{3}{*}{$\begin{array}{l}\text { Yearlings } \\
\text { Replacement } \\
\text { females } \\
\text { Bucks } \\
\text { Does }\end{array}$} & 23 & $8.79^{c} \pm 0.87$ & $40.17^{b} \pm 2.03$ & $49.99^{\mathrm{c}} \pm 1.12$ & $42.69^{c} \pm 0.94$ \\
\hline & & 19 & $11.65^{\mathrm{b}} \pm 0.87$ & $43.59^{b} \pm 2.02$ & $53.13^{\mathrm{b}} \pm 1.11$ & $44.79^{b c} \pm 0.94$ \\
\hline & & $\begin{array}{l}4 \\
60\end{array}$ & $\begin{array}{l}11.32^{\mathrm{b}} \pm 1.35 \\
15.80^{\mathrm{a}} \pm 0.85\end{array}$ & $\begin{array}{l}42.11^{\mathrm{b}} \pm 3.11 \\
49.04^{\mathrm{a}} \pm 1.94\end{array}$ & $\begin{array}{l}52.48^{\mathrm{b}} \pm 1.73 \\
58.73^{\mathrm{a}} \pm 1.07\end{array}$ & $\begin{array}{l}45.96^{\mathrm{b}} \pm 1.46 \\
48.10^{\mathrm{a}} \pm 0.90\end{array}$ \\
\hline \multicolumn{3}{|c|}{ Level of Significance } & NS & NS & $*$ & NS \\
\hline \multirow{3}{*}{ Village } & Gangatia & 31 & $11.56^{\mathrm{b}} \pm 0.83$ & $43.70^{\mathrm{b}} \pm 1.92$ & $53.15^{\mathrm{b}} \pm 1.06$ & $45.11 \pm 0.89$ \\
\hline & Borachala & 22 & $12.46^{\mathrm{a}} \pm 0.91$ & $42.46^{\mathrm{a}} \pm 2.12$ & $54.83^{\mathrm{a}} \pm 1.17$ & $46.08 \pm 0.98$ \\
\hline & Pachpai & 53 & $11.65^{\mathrm{b}} \pm 0.82$ & $45.01^{\mathrm{a}} \pm 1.92$ & $52.77^{\mathrm{ab}} \pm 1.06$ & $44.96 \pm 0.89$ \\
\hline \multicolumn{2}{|c|}{ Level of Significance } & & $* *$ & NS & $* *$ & NS \\
\hline \multirow{3}{*}{$\begin{array}{l}\text { Body } \\
\text { condition }\end{array}$} & Very thin & 2 & $9.67^{c} \pm 1.7$ & $42.95 \pm 3.98$ & $53.22^{\mathrm{b}} \pm 2.18$ & $45.56 \pm 1.84$ \\
\hline & \multirow{2}{*}{$\begin{array}{l}\text { Thin } \\
\text { Good }\end{array}$} & 59 & $12.24^{\mathrm{b}} \pm 0.64$ & $43.02 \pm 1.54$ & $52.75^{\mathrm{b}} \pm 0.82$ & $45.25 \pm 0.69$ \\
\hline & & 45 & $13.75^{\mathrm{a}} \pm 0.66$ & $45.21 \pm 1.54$ & $54.77^{\mathrm{a}} \pm 0.85$ & $45.28 \pm 0.71$ \\
\hline \multicolumn{3}{|c|}{ Level of Significance } & NS & NS & NS & NS \\
\hline Horn & Horned & 92 & $11.66 \pm 0.76$ & $43.56 \pm 1.78$ & $53.83 \pm 0.98$ & $45.98 \pm 0.85$ \\
\hline pattern & Polled & 14 & $12.11 \pm 0.93$ & $43.89 \pm 2.15$ & $53.34 \pm 1.19$ & $44.78 \pm 1.00$ \\
\hline \multicolumn{3}{|c|}{ Level of Significance } & NS & NS & NS & NS \\
\hline \multirow[t]{5}{*}{ Coat color } & Solid Black & 45 & $12.89 \pm 0.79$ & $43.36 \pm 1.84$ & $54.88 \pm 1.01$ & $45.73 \pm 0.85$ \\
\hline & Toggenburg pattern & 38 & $13.50 \pm 0.76$ & $43.98 \pm 1.76$ & $55.20 \pm 0.97$ & $45.73 \pm 0.81$ \\
\hline & Brown Bezoar & 14 & $12.97 \pm 0.86$ & $44.37 \pm 2.01$ & $55.20 \pm 1.10$ & $44.66 \pm 0.93$ \\
\hline & Dutch belt & 2 & $8.0 \pm 2.41$ & $43.17 \pm 5.60$ & $49.27 \pm 3.08$ & $45.60 \pm 2.53$ \\
\hline & Other combination & 7 & $12.07 \pm 0.94$ & $43.77 \pm 2.18$ & $53.43 \pm 1.20$ & $44.10 \pm 1.00$ \\
\hline Range & & 106 & $6.50-28.00$ & $35.00-87.00$ & $44.00-72.00$ & $39.00-56.00$ \\
\hline Mean & & 106 & $14.47 \pm 0.48$ & $46.01 \pm 0.66$ & $56.01 \pm 0.60$ & $46.41 \pm 0.36$ \\
\hline CV\% & & 106 & 33.86 & 14.76 & 10.93 & 7.93 \\
\hline
\end{tabular}

Yearlings, weaning to 11 months; Replacement females, 12 to 18 months; Does, >18 months; BWT, body weight; $\mathrm{BL}$, body length; $\mathrm{CG}$, chest girth; WH, wither height; Means with uncommon superscripts differ significantly (as per DMRT); *, $\mathrm{p}<0.05 ; * *, \mathrm{p}<0.01$; ***, $\mathrm{p}<0.001$; NS, not significant; $\mathrm{n}$, number of goats 


\section{Characteristics of Black Bengal goat}

Table 2: Effect of different factors on reproductive traits in goats

\begin{tabular}{|c|c|c|c|c|}
\hline \multirow{2}{*}{ Factor } & \multirow{2}{*}{ Category } & \multicolumn{2}{|c|}{ Mean $\pm \mathrm{SE}$} & \multirow[b]{2}{*}{ Litter size } \\
\hline & & SPC & KI (days) & \\
\hline \multicolumn{2}{|c|}{ Level of Significance } & NS & NS & NS \\
\hline Age (months) & $\begin{array}{l}\text { Replacement female } \\
\text { Doe }\end{array}$ & $\begin{array}{c}1.09 \pm 0.32(3) \\
1.24 \pm 0.23(28)\end{array}$ & $\begin{array}{c}199.45 \pm 41.05(3) \\
189.58 \pm 28.67(28)\end{array}$ & $\begin{array}{c}1.40 \pm 0.56(3) \\
1.68 \pm 0.39(28)\end{array}$ \\
\hline \multicolumn{2}{|c|}{ Level of Significance } & NS & NS & NS \\
\hline \multirow{3}{*}{ Village } & Gangatia & $1.09 \pm 0.30(11)$ & $204.11 \pm 36.17(11)$ & $1.67 \pm 0.51(11)$ \\
\hline & Borachala & $1.32 \pm 0.31(5)$ & $169.80 \pm 38.11(5)$ & $1.56 \pm 0.54(5)$ \\
\hline & Pachpai & $1.08 \pm 0.22(15)$ & $209.64 \pm 29.92(15)$ & $1.39 \pm 0.38(15)$ \\
\hline \multicolumn{2}{|c|}{ Level of Significance } & NS & $*$ & NS \\
\hline \multirow{3}{*}{ Coat color } & Solid Black & $1.25 \pm 0.31(10)$ & $176.71 \pm 36.17(10)$ & $1.67 \pm 0.54(10)$ \\
\hline & Toggenburg pattern & $1.01 \pm 0.26(13)$ & $226.52 \pm 32.30$ (13) & $1.56 \pm 0.45(13)$ \\
\hline & Brown Bezoar & $1.23 \pm 0.27(8)$ & $180.31 \pm 35.04(8)$ & $1.38 \pm 0.48(8)$ \\
\hline \multicolumn{2}{|c|}{ Level of Significance } & NS & NS & NS \\
\hline \multirow{2}{*}{ TBP } & Natural control & $1.13 \pm 0.16(29)$ & $212.17 \pm 19.42(29)$ & $1.29 \pm 0.28(29)$ \\
\hline & Natural uncontrol & $1.19 \pm 0.41(2)$ & $176.85 \pm 53.61(2)$ & $1.79 \pm 0.71(2)$ \\
\hline \multicolumn{2}{|c|}{ Level of Significance } & NS & $*$ & NS \\
\hline & 1 & - & $158.93 \pm 29.40(28)$ & $1.57 \pm 0.10(28)$ \\
\hline & 2 & - & $230.10 \pm 39.26(3)$ & $1.67 \pm 0.29(3)$ \\
\hline \multicolumn{2}{|c|}{ Level of Significance } & NS & NS & NS \\
\hline \multirow{4}{*}{ KI (days) } & 150 & $0.89 \pm 0.34(3)$ & - & $1.69 \pm 0.58(3)$ \\
\hline & 165 & $0.97 \pm 0.41(2)$ & - & $1.13 \pm 0.71(2)$ \\
\hline & 180 & $1.11 \pm 0.21(24)$ & - & $1.75 \pm 0.36(24)$ \\
\hline & 365 & $1.68 \pm 0.34(2)$ & - & $1.60 \pm 0.60(2)$ \\
\hline \multicolumn{2}{|c|}{ Level of Significance } & NS & NS & NS \\
\hline \multirow{2}{*}{ Litter size } & 1 & $1.14 \pm 0.26(13)$ & $197.98 \pm 34.39(13)$ & - \\
\hline & $2^{+}$ & $1.18 \pm 0.41(18)$ & $191.05 \pm 31.49(18)$ & - \\
\hline \multirow{3}{*}{\multicolumn{2}{|c|}{$\begin{array}{l}\text { Range } \\
\text { Overall mean } \pm S E \\
\text { CV\% }\end{array}$}} & $1-2$ & $150-365$ & $1-2^{+}$ \\
\hline & & $1.10 \pm 0.05(31)$ & $188.55 \pm 8.82(31)$ & $1.58 \pm 0.09(31)$ \\
\hline & & 27.27 & 25.45 & 31.65 \\
\hline
\end{tabular}

SPC, service per conception; KI, kidding interval; TBP, type of breeding practices; Replacement females, 12 to 18 months, Does, $>18$ months; *, $p<0.05$; NS, non significant; Figures in the parenthesis indicate the number of observation

Numbers of service per conception were $1.09 \pm 0.32$ and $1.24 \pm 0.23$ for replacement females and does. Numbers of service per conception varied from $1.08 \pm 0.22$ (Pachpai) to $1.32 \pm 0.31$ (Borachala). Coat color and service per conception had significant $(p<0.05)$ effect on kidding interval. Kidding interval was shorter among Solid black goats (176.71 \pm 36.17 days) compared to those with Toggenburg color patterned goats $(226.52 \pm 32.30 \mathrm{~d})$ and Brown goats ( $180.31 \pm 35.04 \mathrm{~d}$ ). Age, village, coat color, type of breeding practices, service per conception and kidding interval had no effect $(p>0.05)$ on litter size of goats. Litter size was higher in does $(1.68 \pm 0.39)$ than replacement females $(1.40 \pm 0.56)$. Litter size was higher in solid Black (1.67 \pm 0.54$)$ among other two coat color goats Toggenburg (1.56 \pm 0.45$)$ and Brown (1.38 \pm 0.48$)$

\section{Discussion}

Katsumata et al. (1984) found that the average body weight of Black Bengal goat was $15.00 \mathrm{~kg}$ which is almost similar to the present study. Tesfaye (2009) found a body weight of $12.73 \pm 0.13 \mathrm{~kg}$ in indigenous goats in Ethiopia which is almost similar to the body weight of replacement females and bucks. Paul (2008) reported the body weight of bucks and does at 12 months of age as $14.20 \pm 0.20$ and $12.40 \pm 0.41 \mathrm{~kg}$ respectively which are higher than the body weight of bucks and replacements females observed in the present study. Mamabolo et al. (2010) observed the body length of goats in South Africa as 56 to $98 \mathrm{~cm}$ at village level which is higher that obtained in the present study. Paul (2008) reported the body lengths of Black Bengal Bucks and does as $46.50 \pm 0.77$ and $42.15 \pm 0.55 \mathrm{~cm}$, respectively which is closer to the body weight of replacement females found in this present study. Katsumata et al. (1984) observed an average body length for does of $46.6 \pm 0.3 \mathrm{~cm}$ which strongly agrees with the results obtained in the present study. Mamabolo et al. (2010) reported the wither height of goats in South Africa was 51 to $75 \mathrm{~cm}$ at village level 
which is higher from the present study. Mamabolo et al. (2010) reported the wither height of goats in South Africa as 51 to $75 \mathrm{~cm}$ at village level which was higher from the present study. Paul (2008) found the wither height of Black Bengal bucks and does at 12 months of age as $46.90 \pm 0.33$ and $43.10 \pm 0.74 \mathrm{~cm}$ respectively which strongly agrees with the results of wither height of bucks and replacement females obtained in this present study though the wither height of does was higher in the present study.

Ahmed (2006) observed the average kidding interval, litter size and service per conception of Black Bengal Goats were $193 \pm 9.80$ d, 1.94 \pm 0.56 and $1.5 \pm 0.69$, respectively which strongly support the present study. Mamabolo et al. (2010) reported average kidding interval of goats in South Africa at village level was 145-148 d which is shorter from the present study. Mamabolo et al. (2010) reported average litter size of goats in South Africa at village level as 1.5 which is almost similar to the present study. Body weight, body length, chest girth and wither height of adult females were higher than other age groups. Litter size was higher in solid black goats. Less service was required for replacement females.

Results obtained from this study were based on the field survey taking rural community goat raisers' opinion, direct measurement and weighing of animals. It was revealed that variation in age, coat color and location had a great effect on the morphometry and production of Black Bengal goats. Results indicate that body weight, body length, chest girth and wither height of adult females was higher than other age groups. It was also observed that Toggenburg coat colour patterned goats were heavier than other coat color goats. Replacement females were found to be superior to doe in service per conception while they were inferior in kidding interval. Goats of Gangatia were found to be superior to goats of Borachala in litter size and while they were inferior in service per conception and kidding interval. Goats of Pachpai village were found to be superior to goats of Gangatia in service per conception while they were inferior in kidding interval and litter size. Solid Black goats were found to be superior to Toggenburg pattern and Brown Bezoar goats in kidding interval and litter size while they were inferior to service per conception. Abortion rate was lower in Solid Black than Toggenburg pattern and Brown Bezoar. Kid mortality was found to be lower in Solid Black goats than Toggenburg pattern and Brown Bezoar.

\section{Conclusion}

The body weight, body length, chest girth and wither height of adult females were higher than other age groups. Variation in age, coat color and location had a great effect on the morphometry and production of Black Bengal goats. Results thereby indicated an opportunity for improvement of rural Black Bengal goats through a pure breeding program.

\section{Acknowledgement}

We acknowledge the financial support and active cooperation of UNEP-GEF-ILRI FAnGR Asia Project, Department of Animal Breeding and Genetics, Bangladesh Agricultural University, Mymensingh and Bhaluka ADP, World Vision Bangladesh respectively.

\section{References}

Akhter S, Husain SS, Chowdhury A, Munzur, MM and Dev GK (2006). Estimation of variance components and prediction of breeding value for some economically important traits of Black Bengal goat. Ban. J. Anim. Sci. 35: 20-26.

Amin MR, Husain SS and Islam ABMM (2001). Reproductive Pecularities and Litter Weight in Different Genetic Groups of Black Bengal Does. Asian-Aust. J. Anim. Sci. 14: 297301.

Amin MR (2000). Genetic Improvement of Production Traits in Selective breeding and Crossbreeding. PhD Thesis. Dept. Anim. Breeding and Genetics, Bang. Agri, Univ., Mymensingh.

DLS (2009). Department of Livestock Services. Livestock statistics. Memeogram. Dhaka, Bangladesh.

Devendra C and Burn M (1983). Goat Production in the Tropics. Commonwealth Agricultural Bureaux, UK.

Draft SFYP (2010). The Draft Sixth Five Year Plan (2011-2015). Workshop of Planning Commission, Government of Bangladesh. DLS, Dhaka.

Faruque MO and Khandaker MAMY (2007). Recent advances of Goat Genotyping in Bangladesh. Genotyping for Breed and Type Determination. In: Proc. Workshop on Recent Advances of Livest. Genotyping in Bangladesh. Genotyping of goat and buffaloes for Breed Type Determination. May, 10, 2007 in BARC, Dhaka, Bangladesh.

Husain (2004). Preservation of buck semen and their use in Artificial Insemination for Rapid Genetic Improvement of Rural Goats 


\section{Characteristics of Black Bengal goat}

population. Bangladesh Agricultural Research Systems, Mymensingh.

Husain SS, Amin MR and Islam ABMM (1998). Goat production and its breeding strategy in Bangladesh. In: proc. $1^{\text {st }}$ National Workshop on Animal Breeding, Bangladesh Agri. Univ., Mymensingh, November 26, 1998. 17-36.

Husain SS (1993). A study on the productive performance and genetic potentials of Black Bengal goats. PhD Thesis, Dept. Anim. Breeding and Genetics, Bang. Agri. Univ., Mymensingh.

Islam MR, Amin MR, Kabir AKMA and Ahmed MU (2009). Comparative study between semiintensive and scavenging production system on the performance of Black Bengal goat. J. Ban. Aril. Univ. 7: 79-86.

Katsumata MT, Amanao T, Nozawa K, Tsunoda K, Namikawa T, Tsubota Y, Hasnath MA, Mostafa KG and Faruque MO (1984). Body measurement and blood protein variations of the native goats in Bangladesh. In: Genetic Studies on Breed Differentiation of Native Domestic Animals in Bangladesh. Tokyo University of Agriculture. 2: 75 - 92.

Mamabolo MJ, Web EC, Preez EK and Morris SD (2010). Reproductive status of goats in communal system in South Africa. Department of Animal and Wildlife Science, University of Pretoria, South Africa.
Nozawa K, Katsumata M, Hasnath MA, Mostafa KG and Faruque MO (1984). Coat color Polymorphism in the Black Bengal Goats. In: Genetic Studies on Breed Differentiation of Native Domestic Animals in Bangladesh. Tokyo University of Agriculture, 2: 87-99.

Paul S (2008). Characterization of Black Bengal goat. MS Thesis. Dept. Anim. Breeding and Genetics. Bang. Agri. Univ., Mymensingh.

SPSS Windows for version-14.0. Release on 27.10.2005. (Microsoft Corp. 1998). Trends SPSS Inc Michigan Avenue, Chicago, IL. 19-182.

Tesfaye G, Sisay L, Dereje T, Abebe $M$ and Solomon G (2006). Growth and reproductive performance of Central Highland goats in North Shoa and South Wollo. Proc. $1^{\text {st }}$ Annual Conf. completed Livest. Research Activity. Amhara Region Agricultural Research Institute, Bhar Dhar, Ethiopia. 7-13.

Tesfaye $T$ (2009). Characterization of goat production systems and on-farm evaluation of the growth performance of grazing goats supplemented with different protein sources in Metema Worde, Amhara Region, Ethiopia. MSc Thesis. Dept. Anim. Sci. Haramaya University. 